\title{
DETECTION OF PROTEIN STOICHIOMETRIC PHOSPHORYLATION USING Phos-tag SDS-PAGE
}

\author{
Doan Minh Thu ${ }^{1}$, Nguyen Thi Minh Viet ${ }^{2}$, Pham Thi Kim Lien ${ }^{1, \bowtie}$ \\ ${ }^{I}$ VNUK Institute for Research and Executive Education, The University of Danang \\ ${ }^{2}$ Graduate School of Comprehensive Human Sciences and Faculty of Medicine, University of Tsukuba, \\ Tsukuba, Japan
}

${ }^{\square}$ To whom correspondence should be addressed. E-mail: lien.pham@vnuk.edu.vn

Received: 27.4.2019

Accepted: 25.11.2019

\section{SUMMARY}

Protein phosphorylation plays an important role in many cellular signalings which are relating to many diseases. Therefore, a variety of biochemical techniques has been developed to study protein phosphorylation in cells. Protein phosphorylation has traditionally been detected by radioisotope phosphate labeling of proteins with radioactive ATP. Phosphorylation site-specific antibodies are now available for the analysis of phosphorylation status at target sites. However, these antibodies cannot be used to detect unidentified phosphorylation sites. Recently, the Phos-tag technology has been developed to overcome the disadvantages and limitations of these methods. Phos-tag and its derivatives conjugated to biotin, acrylamide, or agarose, and can capture phosphate monoester dianions bound to serine, threonine, and tyrosine residues, in an amino acid sequence-independent manner. The grouping of the Phos-tag will alter the mobility of protein on the gel depending on the amount of serine, threonine or tyrosine which are phosphorylated. Here, we describe the method to detect the phosphorylation of Pop2 protein, one of the exonucleases in the Ccr4-Not complex regulating the shortening of poly(A) tail of mRNAs using phosphate affinity Phos-tag SDS-PAGE. We observed clear electrophoretic 04 shift bands of Pop2-3XFlag under unstressed conditions. This is the first study which observes Pop2 phosphorylation in normal culture conditions. This study showed the convenience and advantages of Phos-tag SDS-PAGE for research on molecular mechanisms regulating the function of protein.

Keywords: protein phosphorylation, Phos-tag, Western blotting, phosphate monoester and serine

\section{INTRODUCTION}

Phosphorylation is one of important posttranslational modifications that regulate protein functions, locations and interactions in eukaryotes (Hunter, 1995; Hunter 2000). This process is catalyzed by protein kinases and is the process of attaching phosphate groups to serine (Ser), threonine (Thr) or tyrosine (Tyr) on proteins (Takahiro et al., 2016). Phosphorylation is involved in controlling many cellular activities such as apoptosis, gene expression regulation, cell cycle and energy metabolism. Abnormal phosphorylation may be the cause of diseases such as cancer or neurodegeneration (Newman et al., 2014). The development of methods to verify protein phosphorylation is an important approach for analyzing biological and pathological processes (Eiji Kinoshita et al., 2006).

There are different analytical methods to check protein phosphorylation, such as radioisotope ( $\gamma$ 32P $]$-ATP), hybridization with specific antibodies, microarray and mass spectrometry (Newman et al., 2014). Each method has its own advantages and limitations. The method of radioisotope is limited by the number of samples, safety, waste handling obstacles and it is not suitable for in vivo analysis. Using antibodies is currently popular but it can only be used when it is known about the location and sequence of phosphorylated amino acids. Other methods such as microarray or mass spectra require high equipment, materials and procedures. Recently, the Phos-tag technique has 
been developed to improve the limitations of the above-mentioned methods. Phos-tags and its derivatives are combined with biotin. The Phos-tag has a hole in two metal ions suitable for mounting the phosphomonoester dianion root (Asunori et al., 2015). Therefore, Phos-tag technique can detect monoester dianion phosphate group which associated with serine, threonine and tyrosine residues in a manner independent on amino acid sequence. In principle, an acrylamide-pendant $\mathrm{Mn}^{2+}$-Phos-tag is used as a novel additive in a separating gel for normal SDS-PAGE. In a separating gel containing co-polymerized Phos-tag, the degrees of migration of phosphoproteins are less than those of their nonphosphorylated counterparts because the tag molecules trap phosphoproteins reversibly during electrophoresis. On the basis of this principle, a novel type of gel electrophoresis has recently been established, $\mathrm{Mn}^{2+}$-Phos-tag SDS-PAGE, for the separation of phosphoproteins from their corresponding nonphosphorylated analogs (Eiji Kinoshita et al., 2006). The advantages of this approach compared to other methods is: (1) simultaneously detecting multiple phosphorylated forms, (2) safe and low cost, (3) very simple method and not requiring many techniques or equipment.

Here, we describe an approach to detect the phosphorylation of Pop2 protein, a subunit of the Ccr4-Not complex, involved in regulating the expression of many genes in the cell. A previous study showed that Pop2 was phosphorylated when cells were starved (A. Sakai et al, 1995). However, using the Phos-tag TM technique, we discovered that Pop2 is phosphorylated in multiple forms even in normal culture conditions. At the same time, we also optimized the process to clearly observe Pop2 phosphorylation. Using this procedure, we found that Pop2 is highly phosphorylated under normal culture conditions, this phosphorylation may play an important role in Pop2 function in cell.

\section{MATERIALS AND METHODS}

\section{Strains, plasmids, media and general methods}

Escherichia coli DH5 $\alpha$ was used in DNA and plasmids manipulation. Saccharomyces cerevisiae 10B [MATA ade2 bp1 can1 leu2 his3 ura3 GAL psi + HOp-ADE2-HO 3 'UTR] was used for protein expression. Plasmid pFA6a-kanMX6 [kanMX6] was used to take 3XFLAG fragment, plasmid YCplac33 [URA3, CEN-ARS] was used to express protein in yeast. The media used in the study include: LB (10 $\mathrm{g} / \mathrm{L}$ trypton, $5 \mathrm{~g} / \mathrm{L}$ yeast extract, $5 \mathrm{~g} / \mathrm{L} \mathrm{NaCl}$ ), LBAmp (LB medium supplemented with ampiciline 50 $\mu \mathrm{g} / \mathrm{mL})$, YPD (10 g/L yeast extract, $20 \mathrm{~g} / \mathrm{L}$ peptone, $0,2 \%$ glucose $),$ SC $(6.7 \mathrm{~g} / \mathrm{L}$ Bacto-yeast nitrogen base w/o amino acids, $20 \mathrm{~g} / \mathrm{L}$ glucose, $2 \mathrm{~g} / \mathrm{L}$ Dropout mix). Basic methods in cell culture are performed as described in "In yeast genetics Methods" (Adam et al., 1997).

\section{Construction of YCplac33/POP2-3XFLAG}

PCR with L1/L2 specific primers to amplify POP2 gene from $S$. cerevisiae 10B strain. The 3XFLAG tag was taken from the plasmid pFA6a-kanMX6 with the L2/L3 primers. Plasmid YCplac33-Pop23 XFLAG is constructed using the In-Fusion ${ }^{\circledR}$ HD Cloning Plus kit (Takara, Japan). The product of the fusion reaction was transformed into E. coli $\mathrm{DH} 5 \alpha$ cell. Transformation mixture was spread on LBAmp, incubated $37^{\circ} \mathrm{C}$, for $16-18$ hours. E. coli $\mathrm{DH} 5 \alpha$ cell carrying recombinant plasmids grew on LBAmp and formed white colonies. Recombinant plasmids was isolated and checked by PCR and sequencing.

Plasmid Ycplac33 and YCplac33-POP23XFLAG are independently transformed into $S$. cerevisiae $10 \mathrm{~B}$ cells. Transformation mixture is spread on SC-URA medium, incubated at $30^{\circ} \mathrm{C}$, for 2-5 days. The transformants were collected and checked by PCR method and named as $S$. cerevisiae 10B/YCplac33 and_10B/ YCplac33-POP2-3XFLAG strains.

\section{SDS-PAGE and Western blotting analysis}

10B/YCplac33-POP2-3XFLAG strain was precultured and transferred into $10 \mathrm{~mL}$ of SC-URA medium, $250 \mathrm{rpm}$ at $30^{\circ} \mathrm{C}\left(\mathrm{OD}_{600} \sim 0.2\right)$. Cells grown to exponential phase were subjected to a mild alkali treatment-based protein extraction method (Kushnirov VV et al., 2000). Samples were loaded onto SDS-PAGE gel. Phos-tagTM (Wako, USA) was added in mix of SDS-PAGE gel when analyzing protein phosphorylation. The final concentration of Phos-tagTM was $5 \mathrm{mmol} / \mathrm{L}$. SDS-PAGE gel was then electroblotted onto Immobilon polyvinylidene difluoridemembranes (MerckMillipore, USA). Blots were blocked for $1 \mathrm{~h}$ at room temperature with TBS$\mathrm{M}$ buffer containing $20 \mathrm{mM}$ Tris- $\mathrm{HCl}$ (pH 7.5), 150 $\mathrm{mM} \mathrm{NaCl}$, and $5 \%$ non-fat dry milk, and then incubated with 1:1,000-diluted primary antibodies in TBS-M buffer overnight at $4^{\circ} \mathrm{C}$. After three final washes with TBS buffer containing $20 \mathrm{mM}$ Tris- $\mathrm{HCl}$ (pH 7.5) and $150 \mathrm{mM} \mathrm{NaCl}$, blots were incubated 
with secondary antibodies, and were developed using enhanced chemiluminescence detection kits (Merck Millipore, USA). Signal intensities were quantified by Image Studio software (LI-COR).

\section{RESULTS AND DISCUSSION}

\section{The expression of Pop2-3XFlag protein}

Transformants 10B/ YCplac33-POP2-3XFLAG were grown to exponential phase and then subjected to a mild alkali treatment-based protein extraction method and analyzed by SDS-PAGE and Western blotting. Blots was analyzed by anti-Flag antibody. As shown in Figure 1, we observed a band in sample of cell extracts of 10B/YCplac33-POP2-3XFLAG appropriated for the molecular weight of Pop2$3 \mathrm{Xflag}(\sim 52 \mathrm{KDa})$. There are no bands observed in sample of 10B cell carying YCplac33
(10B/YCplac33). Plasmids and strains used for expression of Pop2-3XFlag were shown in Table 1.

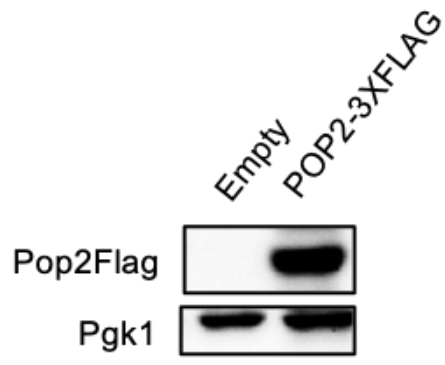

Figure 1. The expression of Pop2-3Xflag. Wild-type cells harboring YCplac33 (Empty), YCplac33-POP2-3XFLAG (POP2-3XFLAG) were grown at $30^{\circ} \mathrm{C}$ until exponential phase. Extracts prepared from each strain were run on conventional gels, then immunoblotted with anti-Flag antibody.

Table 1. List of plasmids and strains constructed and used in this study.

\begin{tabular}{|c|c|c|}
\hline \multicolumn{3}{|c|}{ List of trains } \\
\hline Strains & Genotype & Source or reference \\
\hline $10 \mathrm{~B}$ & $\begin{array}{l}\text { MATa ade2 trp1 can1 leu2 his3 ura3 GAL psi+ HOp-ADE2-HO } \\
\text { 3' UTR }\end{array}$ & Hata et al., 1998 \\
\hline 10B/YCplac33 & $\begin{array}{l}\text { MATa/MATa ade2/ade2 trp1/trp1 can1/can1 leu2/leu2 his3/his3 } \\
\text { ura3/ura3 YCplac33 }\end{array}$ & This study \\
\hline $\begin{array}{l}\text { 10B/Ycplac33-POP2- } \\
\text { 3XFLAG }\end{array}$ & $\begin{array}{l}\text { MATa/MATa ade2/ade2 trp1/trp1 can1/can1 leu2/leu2 his3/his3 } \\
\text { ura3/ura3 YCplac33-POP2-3XFLAG }\end{array}$ & This study \\
\hline \multicolumn{3}{|c|}{ List of plasmids } \\
\hline Name & Relevant markers & Source or reference \\
\hline YCplac33 & URA3, CEN-ARS & Gietz et al., 1988 \\
\hline YCplac33-POP2-3XFLAG & URA3, CEN-ARS, POP2FLAG & This study \\
\hline pFA6a-kanMX6 & kanMX6 & Longtine et al., 1998 \\
\hline
\end{tabular}

\section{Analysis of Pop2 phosphorylation using Phos- tagTM SDS-PAGE}

Understanding the post-translational modification plays an important approach in the functional analysis of a protein. There have been only a few studies of post-translational regulation of the Ccr4/Not complex. Pop2, a subunit of Ccr4/Not complex was reported that is phosphorylated by protein kinase Yak1 under starved condition, the phosphorylation was not observed under normal growth conditions (Sakai et al., 1992). We examined the patterns of Pop2 protein using Phos-tagTM SDS-
PAGE under normal growth condition. We observed multiple shifted bands Pop2-3XFlag (Figure 3). These shifted bands are probably corresponding to the phosphorylated forms of Pop2-3XFlag protein which was not able to observed in previous study by another method (Sakai et al., 1992). Basing on the result of this method, we have analyzed the characteristic and physiological roles of those phosphorylation forms of Pop2. Our results suggested that Pop2 is phosphorylated at S39 in a Pho85-dependent manner upon glucose availability. Moreover, this post-transcriptional modification of Pop2 specifically contributes to the glucose 
repression of the stress response genes, HSP12 and HSP26 (Lien et al., 2019). Methods for determining the phosphorylation status of proteins are very important with respect to the evaluation of diverse biological and pathological processes. Therefore, this study has shown the evidence for the advantages of Phos-tagTM SDS-PAGE for that aspect.

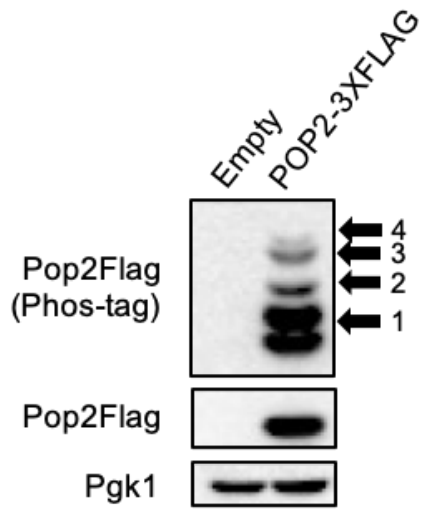

Figure 3. The migration of Pop2-3Xflag in Phos-tagTM SDS-PAGE. Wild-type cells harboring YCplac33 (Empty), YCplac33-POP2FLAG (POP2-3XFLAG) were grown at $30^{\circ} \mathrm{C}$ until exponential phase. Extracts prepared from each strain were run on Phos-tagTM and conventional gels, then immunoblotted with anti-Flag antibody. Migrated Pop2Flag is indicated with arrows and numbers according to the positions.

In this report, we have introduced the method which is the application of polyacrylamide-bound $\mathrm{Mn}^{2+}$-Phos-tag to SDS-PAGE for the separation of phosphorylated proteins in the gel. By means of the subsequent general method of Western Blotting, phosphorylated Pop2 can be visualized as a slower migration band compared with a corresponding dephosphorylated protein. This method revealed the existence of the isotypes of a multiphosphorylated protein as different migration bands as well as the time course ratio of phosphorylated and dephosphorylated proteins in an SDS-PAGE gel. This method requires a general minislab PAGE system and an additive, acrylamide-pendant $\mathrm{Mn}^{2+}$ Phos-tag without any special apparatuses, radioisotopes, or fluorescent probes. In addition, this method could be used as preceding general method for a lot of methods for further analysis protein activities such as gel staining, Western blotting, mass spectrometry.

The phosphorylation status of a particular protein is determined by the regulation of the opposing activities of protein kinase and phosphatase. Perturbations in the equilibrium fundamentally affect the numbers of cellular events and are also involved in many diseases. Therefore, the development of a more specific and efficient method to detect protein phosphorylation has attracted great interest toward phosphoproteome studies in the biological and medical fields. Phostag SDS-PAGE have recently been used in many studies to uncover the physiological activities of kinases (Yasunori Sugiyama et al., 2015). We believe that phosphoproteomics would progress greatly by combining the Phos-tag technology and existing methods using high quality antibodies (Kaufmann et al., 2001) and convenient mass spectrometers (Nakanishi et al., 2005, Takeda et al., 2003).

\section{CONCLUSION}

In summary, we describe here a modification of the technique of Phos-tag SDS-PAGE that allows the separation of multiple phosphorylated forms of Pop2, enabling identification of the number of phosphorylated sites and the overall phosphorylation stoichiometry under defined conditions. Further experiments also need to be done to determine the protein kinase that catalyzes the phosphorylation of Pop2 and the phosphorylated amino acid sites. When used in conjunction with Western blotting using well-characterized phospho specific antibodies, this approach can yield important information regarding sequential and hierarchical phosphorylation events in the regulation of Pop2 function. Here we showed the superiority of Phos-tag SDS-PAGE in analysis of protein physiological activities.

Acknowledgement: We thanks to Department of Molecular Cell Biology, Graduate School of Comprehensive Human Sciences, University of Tsukuba, Japan for supporting us about equipments and materials to conduct the experiments. We thanks Prof. Irie Kenji and Irie lab's members for their supports to optimization of Phos-tag SDS-PAGE and Ms. Trang Le for her support in English editing. This work was supported by VN-UK Science and Technology Grant.

\section{REFERENCES}

Adams A, Gottschling DE, Kaiser C (1997) Methods in yeast genetics. Cold Spring Harbor Labora- tory Press, Cold Spring Harbor, NY.

Asunori Sugiyama, Syouichi Katayama, Isamu Kameshita, Keiko Morisawa, Takuma Higuchi, Hiroshi Todaka, Eiji Kinoshita, Emiko Kinoshita-Kikuta, Tohru Koike, 
Taketoshi Taniguchi, Shuji Sakamoto (2015) Expression and phosphorylation state analysis of intracellular protein kinases using Multi-PK antibody and Phos-tag SDS-PAGE. MethodsX 2 (2015) 469-474.

Eiji Kinoshita, Emiko Kinoshita-Kikuta, Kei Takiyama, and Tohru Koike (2006) Phosphate-binding Tag, a New Tool to Visualize Phosphorylated Proteins. Mol Cell Proteomics 5(4):749-57.

H Takeda, A Kawasaki, M Takahashi, A Yamada, T Koike (2003) Matrix-assisted laser desorption/ionization time-offlight mass spectrometry of phosphorylated compounds using a novel phosphate capture molecule, Rapid Communications in Mass Spectrometry, 17: 2075-2081.

Hunter (1995) Protein kinases and phosphatases: the yin and yang of protein phosphorylation and signaling. Cell 80, $225-236$

Hunter (2000) Signaling-2000 and beyond. Cell 100: 113-127.

Kaufmann, H., Bailey, J. E., and Fussenegger, M. (2001) Use of antibodies for detection of phosphorylated proteins separated by two-dimensional gel electrophoresis. Proteomics 1: 194-199

Kushnirov VV (2000) Rapid and reliable protein extraction from yeast. Yeast 16(9):857-60.

Lien PTK, Viet NTM, Mizuno T, Suda Y, Irie K (2019) Pop2 phosphorylation at S39 contributes to the

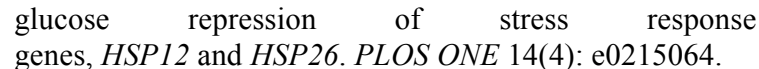

Sakai A, Chibazakura T, Shimizu Y, Hishinuma F (1992) Molecular analysis of POP2 gene, a gene required for glucose-derepression of gene expression in Saccharomyces cerevisiae. Nucleic Acids Research. 1992; 20(23):6227-33

Nakanishi T, Ohtsu I, Furuta M, Ando E, Nishimura O (2005) Direct MS/MS analysis of proteins blotted on membranes by a matrix- assisted laser desorption/ionization-quadrupole ion trap-time-of-flight tandem mass spectrometer. J Proteome Res 4: 743-747

Newman RH, Zhang J, Zhu H (2014) Toward a systemslevel view of dynamic phosphoryla- tion networks. Front Genet 5:263.

Takahiro Horinouchi, Koji Terada, Tsunehito Higashi, and Soichi Miwa (2016) Using Phos-Tag in Western Blotting Analysis to Evaluate Protein Phosphorylation. Methods Mol Biol Vol. 1397.

Yasunori Sugiyama, Syouichi Katayama, Isamu Kameshita, Keiko Morisawa, Takuma Higuchi, Hiroshi Todaka, Eiji Kinoshita, Emiko Kinoshita Kikuta, Tohru Koike,Taketoshi Taniguchi, Shuji Sakamoto (2015) Expression and phosphorylation state analysis of intracellular protein kinases using Multi-PK antibody and Phos-tag SDS-PAGE. Methods $X$ : 2215-0161.

\section{PHÁT HIÊN SỬ PHOSPHORYL HOÁ CỦA PROTEIN SỬ DỤNG PHOS-TAG SDS-PAGE}

\section{Đoàn Minh Thu ${ }^{1}$, Nguyễn Thị Minh Việt ${ }^{2}$, Phạm Thị Kim Liên ${ }^{1}$}

${ }^{I}$ Viện Nghiên cúu và Đào tạo Việt - Anh, Đại học Đà Nã̃ng

${ }^{2}$ Đại học Tsukuba, Nhật Bản

\section{TÓM TẮT}

Sự phosphoryl hóa đóng vai trò quan trọng đối với việc kiểm soát nhiều con đường truyền tín hiệu trong tế bào. Sự rối loạn của quá trình phosphoryl hóa protein là nguyên nhân của nhiều bệnh lí. Do vậy, rất nhiều phương pháp được phát triển để kiểm tra sự phosphoryl hóa của protein trong tế bào. Sự phosphoryl hóa của protein trước đây được phát hiện bằng cách sử dụng đánh dấu đồng vị phóng xạ gốc phosphate. Nhiều nghiên cứu sử dụng kháng thể đặc hiệu cho gốc amino acid được phosphoryl hóa. Tuy nhiên các kháng thể này chỉ được sử dụng khi đã xác định gốc amino acid được phosphoryl hóa và trình tự amino acid có vị trí phosphoryl hóa. Gần đây, kĩ thuật Phos-tag được phát triển, có những ưu điểm vượt bậc và khắc phục được những hạn chế của phương pháp sử dụng kháng thể và đồng vị phóng xạ. Phos-tag và những dẫn xuất của nó được gắn với biotin, acrylamide hay agarose để có thể bắt nhóm phosphate monoester ở serine, threonine và tyrosine mà không phụ thuộc vào trình tự amino acid. Việc gắn nhóm Phos-tag sẽ làm thay đổi sự phân tách của protein trên gel tuỳ thuộc vào số lượng serine, threonine hay tyrosine được phosphoryl hoá. Ở đây chúng tôi mô tả kỹ thuật Phos-tag, quy trình để phát hiện sự phosphoryl hóa của protein Pop2, là protein tham gia điều hoà quá trình làm ngắn đuôi poly $(\mathrm{A})$ của mRNA. Đây là nghiên cứu đầu tiên quan sát được sự phosphoryl hoá của Pop2 ở điều kiện nuôi cấy bình thường. Kết quả này chứng minh cho sự tiện lợi và những ưu điểm của Phostag SDS PAGE trong phân tích hoạt tính sinh lí của protein trong tế bào.

Từ khoá: phosphoryl hoá protein, Phos-tag, lai Western, phosphate monoester, serine 